\title{
Professing Contradictions: Knowledge Work and the Neolib- eral Condition of Academic Workers
}

\author{
Marco Briziarelli* and Joseph L. Flores** \\ *University of New Mexico, Albuquerque, US, mbriziarelli@unm.edu \\ **University of New Mexico, Albuquerque, US, jlflores2@unm.edu
}

\begin{abstract}
In this paper, we will provide an interpretation of the condition of academic labour, which is understood as a particular kind of knowledge work and labour. Our objective is to explore the contradictory condition of academics in terms of class position, production of value and subjectivity, showing both its idiosyncrasies as well as its alignment with the broader experience of working in current post-Fordist capitalism. First, paying particular attention to the US media and communication departments that develop critical cultural scholarship, we reflect on the unresolved impasse deriving from the distinction of mental and manual labour. Second, we describe this profession as being characterized by a contradictory class location and a valorization that relies on a continuous negotiation for better exchange rate between intellectual and financial capital. Third, we consider how such a context subjectively translates in an ever-resolved condition of 'employability,' which comprises vocational aspects and the necessity dictated by the hope to reach stability and recognition.
\end{abstract}

Keywords: Knowledge Work, Knowledge Labour, Mental and Manual Labour, Gramsci, Bourdieu, Terranova, Free Labour, Employability

Throughout recent history, intellectuals integrated in academia have consistently inhabited a liminal position in the social organisation, which has uncomfortably placed them in between intellectual and manual labour, and in a contradictory class position between subalternity and dominance. Scholars of humanities and social sciences, especially, are rarely perceived as workers contributing to the material production in a given society.

In the specific cultural and political context considered in this paper, i.e. US humanities departments, scholars are caught in the cross fire between the neo-liberal restructuration of higher education (Radder 2010) and Trump's overt populist antiintellectualism. While the two tendencies are clearly connected, they exert pressure at different levels: on the one hand, the neoliberal model of higher education pushes to increasingly commodify and privatize universities by asserting economic efficiency, high productivity, anti-unionism, the extraction of value from both students and instructors, and pursue a 'divide and conquer' strategy against any kind of collective resistance by the powerful means of meritocratic ideology; on the other, Trumpism professes the value of personal authenticity, genuine vernacularity and healthy American pragmatism, trading 'book smartness' and abstract knowledge for 'street smartness' and immediate concrete results. As a consequence, academic labour progressively enters a condition of precarity and lack of recognition.

In relation to such context, in this paper we will provide an interpretation of the condition of the academic profession, which is understood as a particular kind of knowledge work and labour. Explicitly, we consider the diverse venue and institutional frameworks that higher education has historically taken in different regions while 
being mindful of the limits in the generalization of our analysis. In a country that has consistently been at the forefront of the neoliberalization process, tenured positions in US research institutions appear to the populist right-wing as the exemplification of status quo, a remanence of 'pre-modern' privilege unfairly granted to 'progressive' intellectuals.

Thus, in relation to such depiction, our objective is to explore its contradictory condition in terms of class position, production of value and subjectivity, by showing both its idiosyncrasies as well as its alignment with the broader experience of working in current post-Fordist capitalism. First, by paying particular attention to the media and communication departments that develop critical cultural scholarship, we reflect on the unresolved impasse deriving from the distinction of mental and manual labour. Second, we contextualize this profession as knowledge work and labour, being characterized by a contradictory class location and a valorization that relies on a continuous negotiation for better exchange rate between intellectual and financial capital (Bourdieu 1988).

Academic subjectivities are shaped by a variety of tendencies conflicting with each other: living in debt for many years; a condition of existential and material precarity while aspiring to a privileged job security, i.e. tenure; experiencing authorship both as a potential rejection of modern alienation and losing control of their own production by giving up intellectual property rights; and finally attending in the classroom the perplexing liberalization of the student/instructor relationship. We consider such a subjective condition to be synthetized in the condition of 'employability,' which comprises vocational aspects and the necessity dictated by the hope to reach stability and recognition.

\section{The Need to Materialize and Historicize Intellectual Labour}

Said (1993) synthetizes quite eloquently the contradictory position in which intellectuals in the university seem to find themselves: having access to a superior understanding of reality, but also being either out of touch with reality or wrongly invested in it. In this paper, we claim that part of such representation derives from their location in the productive organisation of Western societies. In fact, as suggested elsewhere (Briziarelli 2013), defining the activity of academicians in terms of academic labour that produces value though socially necessary labour time (Marx 1990) does not only serve to push against idealist conceptualizations of the 'intellectual,' but also helps explain the contradictions that inhabit and significantly constrain such fields of action.

Part of the issue is the false distinction between mental and manual labour, which, based on Cartesian ontology, traditionally relegates the former at the margin of material social production. As Gramsci says in a well-known passage of Quaderni (1975):

All men are intellectuals, one could therefore say: but not all men have in society the function of intellectuals [...] When one distinguishes between intellectuals and nonintellectuals, one is referring in reality only to the immediate social function of the professional category of the intellectuals, that is, one has in mind the direction in which their specific professional activity is weighted, whether towards intellectual elaboration or towards muscularnervous effort. This means that, although one can speak of intellectuals, one cannot speak of non-intellectuals, be- 
cause non-intellectuals do not exist. But even the relationship between efforts of intellectual-cerebral elaboration and muscular-nervous effort is not always the same, so that there are varying degrees of specific intellectual activity. There is no human activity from which every form of intellectual participation can be excluded: homo faber cannot be separated from homo sapiens. Each man, finally, outside his professional activity, carries on some form of intellectual activity, that is, he is a "philosopher", an artist, a man of taste, he participates in a particular conception of the world, has a conscious line of moral conduct, and therefore contributes to sustain a conception of the world or to modify it, that is, to bring into being new modes of thought.

Gramsci's materialist reflection enters into conversation with debates that have consistently concerned traditional epistemology and the equally traditional distinction between 'dispositional-knowledge-that' (episteme) on the one hand, and 'propositional knowledge-how' (technê) on the other. Accordingly, for instance, by the statement "she knows how to ride a bicycle" we could alternatively mean that she only knows the theory of riding a bicycle or she only practices riding, but not, for instance, the physics behind it.

Conversely, the implication of the unity of homo faber and homo sapiens is for Gramsci twofold. On the one hand, he intends to go beyond the distinction between intellectual and practical knowledge by the means of a materialist anthropology. Thus, in the same way as Marx (1990) compares the worst architect with the spider and the bee, Gramsci maintains that the creation and interpretation of meaning consistently happen in social practical situations in which thinking and acting become an indissoluble unity. On the other, still linked to the historicity of unity of theory and action, such a materialist perspective suggests that, even when performing as detached agents and omniscient observers of the world, i.e. as "traditional intellectuals" (Gramsci 1975, 474), academic's agency is always historically and socially situated, actively participating in the process of production and reproduction of a given social order.

In our view, Gramsci's culturally materialist reflections on intellectuals help us to understand the ambiguity that historically concerned critical scholarship in humanities departments of US academia. In this sense, we identify two main aspects to be considered. First of all, we claim that the dominance of a selective tradition of cultural studies that has abandoned the "doubleness of culture [... as both] material reality and lived experience" (Eagleton 2000,36) moved the object of study and the agency of scholars to an idealist terrain. That is because all relevant knowledge becomes 'culture,' and culture in turn becomes the ideological product of articulation (Hall 1992) of a discursive hegemony thus tied to a reductive view of power as a symbolic category. Consequently, in the university programs in which critical and cultural studies have shaped scholarship, the work of academicians has been more frequently associated to a deconstructive cultural critique activity rather than productive material labour.

Especially in our field of communication and media studies, talking about academic production of value in the context of informational capitalism seems almost paradoxical because as Discenna (2011) notes, the field of communication has historically failed to consider labour (especially, academic labour) as a possible research per- 
spective. For Discenna, centring academic labour means "calling for a reorientation of the field to the material conditions of our own work," which forces the field of communication to correct the "neglect of labor issues" while conducting research (1844).

In respect to that, willing to push against such tendencies, our intervention intends to highlight the fetishized aspects of the material production of our labour. We intend to correct what for Fuchs (2016) are the competing fetishisms of labourism and culturalism, where the former dissolves culture into a manufactured reflective production, and the latter dissolves economy into signifying symbols. As Denning (2004) notes "work and culture seem to be opposite in a number of ways," suggesting researchers need to understand that, "culture is seen as the equivalent of leisure, not labor; the symbolic, not the material" (93).

The second important aspect to take into account in order to understand academic labour has to do with the fact that current conditions of production in many Western countries have historically emphasized the valorization of knowledge production, circulation and reproduction. Thus, in order to provide a general account of the political economy of academic labour, we place it in the context of knowledge work and informational capitalism.

\subsection{Knowledge Work as the Political Economy of Academic Labour}

The current capitalist context of many Western societies has placed communication and information technologies at the centre of the capitalist production, as platforms for production of goods and employment of labour linked to knowledge production and circulation. Not by accident, the vision of a media driven capitalism as it was foreseen by Horkheimer and Adorno with their 'culture industry' thesis (1974) seems to be confirmed by current dictions such as 'informational capitalism', 'cognitive capitalism,' 'digital capitalism' (Fuchs 2009). As a result, academic labourers, then, are increasingly subject to a post-Fordist, intellectual capitalism that involves the integration of "science, information, linguistic communication, and knowledge in general" (Virno 1996, 267).

The informational disposition of current capitalism develops as the result of the intersection of several factors such as the development of a new mode of production centred around information and communication technology, the emergence of the media using internet platforms, and the overall transition to the logic of production that we could define as industrial - regulated from above by control, managers and a legal framework of contract - to a post-industrial one based on self-regulation, selfenactment and developed communicational and relational capabilities of the worker (Beck 2000).

Not accidentally, the re-organisation of an ample sector of production around ICTs also created a category of skilled workers that manage different levels of knowledge and intellectual activity. Specifically, Bratich (2008) notes that "labor has increasingly become intellectualized in three ways: a) the contents produced (information, symbols, affect); b) the technologization and industrial forms (computer skills now required to run many factory lines) and; c) the collaborative informational networks implemented to produce new and old commodities" (30). In this context, "the brain and its bodily mediations are enabled to engage in organic practices of economic production, surplus-value generation, coproduction, communicative circulation, and productive consumption by new media" (Fuchs 2010, 191).

Appropriately, when considering academic knowledge, it is important to note that, according to a Marxian perspective "any laboring activity, material or immaterial, is productive labor so long as it produces surplus value for a capitalist" (Koloğlugil 
$2015,127)$. Hence, "exploitation today is also the exploitation of human creative capacities" and the "expropriation of the common" (Fuchs 2010, 188). Along the same line, according to Hardt and Negri (2004), "relationships, communication, and knowledge are goods that are produced in common, but are appropriated by capital for economic ends" (150). Noticeably, skills that are acquired from the general intellect (Marx 1973), and skills that are acquired through work specifically in academic knowledge, are centred as the "power of knowledge, objectified" (706). In this way, academic knowledge exists as surplus value in which human intellectual and cognitive abilities are positioned as skills optimal for survival (Koloğlugil 2015).

However, despite its increasing weight in the overall social organisation of production of value, academic knowledge work remains scarcely visible because of its alleged 'immateriality' (Lazzarato 1996), but also, as we will discuss in the next section, by an ambiguous class location.

\subsection{A Contradictory Class Location}

Academic labourers make up a part of the multitude in the way Fuchs understands it (2010) as an inter-class precariat "who produces material or knowledge goods and services directly or indirectly for capital and are deprived and expropriated of resources by capital" (186). By defining class this way, academic knowledge becomes an increasingly permeated layer of exploitation in the academy. As defined by Fuchs, knowledge workers "are wage labourers and produce knowledge goods and services in wage relationships or self-employed labour relations" (187). Perpetually precarious, academic knowledge workers are often in constant flux in class positions, and under the pressure of continued intellectualization (Bratich 2008). As Gorz (2010) notes, capital in its post-industrial age goes beyond coercing all time outside the factory to consuming all mental, social, and cultural factories that exist outside the working hours.

The absence of class definition may be in part caused by the ambiguous class location of academicians. In this sense, a recurrent problem in Marxist class analysis consists of making sense of intermediate class positions that resist localization within the primordial confrontation between 'capitalist' and working class. That is indeed the case of intellectuals integrated in the academic system, who, applying here Wright's taxonomy (1997), occupy a "contradictory class location" (23). In this sense, within the political economy of higher education, like managers in Wright's analysis, academicians hold contradictory interests as a class, similar to the managerial class, as both employed and exerting control. In fact, while they are exploited as employed labourers, especially in the case of graduate students and non-tenure track instructors, yet their highly specialized formation and twofold authority - i.e. status and social visibility as well as recognition and authority in the sense of producer of content also controls graduate and undergraduate students' unpaid labour; in other words, the uncompensated production of knowledge such as voluntary participation in studies, and credited and un-credited work towards the writing of articles. Moreover, their position is also ambiguous as salaried semi-autonomous professionals who do not completely own all the means of production but still exercise extensive control over such production as in teaching and the writing process. According to such a view, academicians move within those interstitial positions, between prerogative and coercion, privileged and oppressive power, another layer of the increasingly growing cultural and 'creative industries' (Hesmondhalgh and Baker 2011), and another facet that contributes to explain how capitalism is capable of reproducing consent in the midst of oppression and injustice. 
In his critical research on higher education, Bourdieu (1988) provides more insights to make sense of such a contradictory class location. He describes the universities as a structured field in which its agents compete for scarce resources and for the "legitimation of particular definitions and classifications of the social world" (23). Bourdieu considers academic labour as producing intellectual and cultural wealth that allows them to shape the way dominant ideology is communicated and recognized in a given society, which, for instance, manifests in the fact that higher education institutions administer a monopoly of certifications, making higher education an important reproductive apparatus of the given social order. Such intellectual and cultural capital is not automatically monetized, thus it requires continuous negotiations in terms of exchange rate with economic capital.

In relation to our argument, Bourdieu's interpretation of academic labour in the political economy of knowledge becomes particularly illuminating. For Bourdieu, academicians experience an important tension between the transformative and reproductive tendencies of knowledge production, exemplified by the tension between heterodoxa and hortodoxa:

It is only when the dominated have the material and symbolic means of rejecting the definition of the real that is imposed on them through logical structures reproducing the social structures (i.e. the state of the power relations) and to lift the (institutionalized or internalized) censorships which it implies [...] that the arbitrary principles of classification can appear as such and it therefore becomes necessary to undertake the work of conscious systematization and express rationalization which marks the passage from doxa to orthodoxy. Orthodoxy [...] opinion, which aims, without ever entirely succeeding, at restoring the primal state of doxa, exists only in the objective relationship which opposes it to heterodoxy $(1977,169)$.

While the contradiction between conservative and transformative knowledge can be attributed to different ideological understandings of academic knowledge production, it also frequently mirrors a stratification between senior established academic workers who try to conserve their position and junior professors who try to challenge those conservative positions via alternative and innovative knowledge. We will explore more in detail how the systemic pressures and the productive practices of the political economy of intellectual labour shape its workers. Thus, by providing an account of both the objective and subjective conditions of academic labour, we assert a materialist analysis of this specific kind of productive activity, by examining the intersection of individual agency and self-understanding within a framework of structural limitations.

\section{Subjective Academic Labourer and Consumptive Production}

In order to conceptualize how academic (knowledge) work furthers precarious positionalities and subjectivities, we need to take into account how this kind of labour frequently operates and enacts a state of class flux, according to which class positions are "not fixed, but dynamic, meaning that in informational capitalism, people have a fluid and transient class status" (Fuchs 2010, 189). Such a fluidity, we believe, signals a general condition of working impermanence that shapes the producing subject 
as well because the worker producing also produces its own consciousness (Marx 1857).

Because of this particular kind of knowledge work, together with the normal features of waged labour as a significant aspect of such creative and meaningful activity, the consciousness of academic labourers is likely to be constituted by the combination of the alienating implications of Marxian 'labour' and the more rewarding Marxian 'work' (Marx 1973). Through free work/labour, people organise their lives around 'creativity' and self-activation (Armano and Murgia 2017) and technology of self-hood (Gill 2014) where the external-direction logic - typical of the Fordist model - is replaced by a new sphere of participation, self-promotion of subjective resources, and self-responsabilization (Salecl 2010). As the concept pioneered by Terranova (2000) suggests, the very ironic multiple sense of being "free" allows our understanding of academicians to navigate in between both Marxian labour and work. We try to make sense of such a compound subjectivity by using the notion of free labour and how it translates into a subjective struggle for employability in which vocation and voluntary work push against debt and precarity.

The vocational aspect is key to understand the dialectics between important degrees of flexibility and freedom, and equally preponderant degrees of subordination and exploitation (Clarke et al. 2012). As Davies and Petersen (2005) observe, it is the voluntary vocation and the promise of a more stable future that makes the double process of subjectification - i.e. as acting subject and exploited 'object' - particularly insidious. Along the same line of argument, Berlant (2011) describes such a dynamic as cruel optimism that maintains professional expectations of recognition, career and work stability that the present academic cannot really guarantee. In those circumstances, the academic worker joins the general tendency of knowledge workers of investing in the construction and maintenance of instrumental social relations.

The dimension of the promise constitutes the persuasive optimistic narrative of the typical US academic career that starts with a lingering condition of debt. First of all, paying off student loans accumulated in the process of financing undergraduate education and for sustaining extra expenses not covered by the exiguous teaching and research assistantship salary; self-financing of most traveling expenses for conferences. Then, once earning a PhD, moving expenses due to temporary visiting appointments to hopefully land a tenure track position, and even more hopefully, being promoted to tenure. In such condition, the promise of a futurible stable position is what allegedly compensates for a perennial condition of debt. In this sense, Lazzarato, in Governing by Debt (2015), argues that under current capitalism, especially in the aftermath of 2008 economic crisis, debt is no longer primarily a question of budget and balance sheets, but a political relation of subjection and enslavement. Debt has gone beyond the numerical to almost approach ad-infinitum, thus implying the impossibility of its pay back. Debt becomes a political economic tool to discipline populations, classes and labour categories, and in this case, intellectual workers.

Academic subjectivities also experience a steady expansion of labour that develops through intensification and de-intensification moments (Gallino 2001). Furthermore, the colonization of previously considered disposable leisure time leads academicians to unpaid work based on such vocational passion of one's own work (Gill 2010; Clarke et al. 2012). Court and Kinman (2008) confirm such a tendency, reporting on a 2005 study corroborating that academics are the one professional category that experience unpaid overtime. As such, because precarious labourers often rely on an increase of labour time to tend to a loss a growing job security, class positionalities are formed based on who capitalizes on general knowledge while working the 
longest for the best available contract. Hence, "the emergence of this class is a characteristic expression of capital's movement under neoliberal conditions to outsource labour to reduce variable capital" (Fuchs 2010, 186).

Thus, the vocational aspect becomes a means of self-exploitation, which links meaningful jobs with partially de-waged value production (Hesmondhalgh and Baker 2011). While both academicians, in particular, and knowledge workers, in general, seem to be aware of the self-managing aspect (Gill 2010), there is indeed an aspect of false consciousness that leads academic workers to idealize work (McRobbie 2015) while carrying out practices of self-exploitation (Lorenz 2012). Again, we stress the previously mentioned need to 'rematerialize' mental labour, because it is such an idealization that allows its concealed (because self-enacted) exploitation (Huws 2014, 102).

However, self-exploitation and the vocational aspects are not simply due to false consciousness, but also to a system that re-signifies knowledge work in terms of employability. In this sense, academic work, from the subjective point of view, is a powerful exemplification of the promise of employability understood as the worker's capability to gain initial employment, maintain it, and continuously produce potential for recycling (Hillage and Pollard 1998).

Employability, then, becomes the subjective way in which the neoliberal restructuration of the job market, defined by flexibility, insecurity, and individualization, manifests (Finn 2000). Employability thus implies the shift of labour control and labour formation to individuals who become self-responsibilized and self-enacted (Giustiniano and Brunetta 2015), ergo, self-exploited: longings to subjectively take control and materially profit from their own life, individuals paradoxically strive to overcome their subjective alienation through mastering their accepted material alienation as a capitalist subject (Bloom 2013, 786). As a result, academic labourers act like reprogrammable workers (Castells 1996), which are continuously in need of updating and reskilling.

In our view, those concepts clustered around employability synthetize the peculiar dialectical combination between the vocational, creative and flexibility aspects, and the level of pressure that the political economy of intellectual labour exerts on its agents that is internalized in terms of self-responsabilization, self-motivation and both exploitation and self-exploitation, which Terranova (2000) powerfully synthetizes in the twofold mode of performing free labour: voluntary as free and unpaid (or underpaid) as for free. Here below, we examine one specific aspect that, in our view, is particularly telling of such conditions: academic publishing.

\subsection{Political Economy of Academic Publishing}

The academic 'free' worker is the one who can assert himself/herself in the world by the privilege of authorship, possibly understood as one evidence of capability of people making history, an apparent victory over alienated labour. That is because authorship, in its broadest sense, expresses a humanist sense of history centred around voluntarism and individual agency summarized by philosopher Pico della Mirandola's concept "homo faber sui" $(1942,192)$. However, as in the well-known Marxian principle on history making (Marx 1907, 5), on the one hand, when they can publish, they do not publish under the condition of their own making because they often forfeit their own property rights and their own argument to the particular politics of publication of a given journal; on the other when they fail to publish, they must frequently cope with violent rejection reviews that can perturb the spirit of the fiercest, stoic virtuoso. 
In the current political economy of journal publishing and knowledge work, especially in our field of communication and media studies, authors also lose control of their own production, thereby giving up intellectual property rights and having their words instrumentalized and decontextualized. As Striphas (2010) notes, "the political economy of academic journal publishing has impinged on cultural studies' capacity to transmit the knowledge it produces" (3) because of how it is constrained by necessities of capitalist accumulation in academia (Peekhaus 2012). As a result, as Wright Mills (1951) already denounced more than six decades ago, "the means of effective communication are being expropriated from the intellectual worker" (159).

The continued corporatization of academic journals resituates perpetual precarity by alienating knowledge workers who are attempting to solidify positions in academia while giving up the rights to their work. By transforming intellectual labour into economically viable property, intellectual workers are not only subject to publishing practices and mandates of their departments and tenure, but their work allows publishers to "compete with one another in the marketplace" (Striphas 2010,6). As academic journals continue to be subject to a growing neo-liberal regime, academic knowledge workers are not only continuously constrained to a capitalist controlled industry, but their work continues to be viewed as a characteristic of the utility of science as measured according to a market criteria (Etzkowitz, Webster and Healey 1998). By being forced to participate in producing knowledge that is not only marketable to the political economy of publication but also profitable, academic knowledge workers have continued to be plagued by the growing fragmentation of academic departments and a continued niche approach to scholarly publication (Readings 1996; Brown, Griffiths and Rascoff 2007).

Striphas (2010) situates academic publishing into five major trends, namely alienation, proliferation, consolidation, pricing, and digitization. For academic knowledge workers who need the publishing industry as a means to justify their positions in the academy, the continuation of knowledge accumulation has allowed capital to permeate the industry of publishing in commercial logic. The continued neo-liberal practices of academic publishing are crucial in highlighting the tensions that exist for knowledge workers because they demonstrate contemporary processes of accumulation and the expanding capitalist control of social production that move to include new strata of producers beyond the "orthodox Marxist emphasis on the industrial proletariat and waged labor" (Peekhaus 2012, 587).

Furthermore, the critical relationship mentioned earlier between orthodoxa and heterodoxa kinds of knowledge also provides a politico-economic explanation related to our considerations on the conditional position of critique. In fact, un-established intellectuals in the field experience a fundamental tension between differentiation and legitimation that reveals the contradictory nature of cultural capital: cultural capital needs to both negate existing knowledge to become desirable (because novelty relates to the progress of knowledge, and because academia lives the enlightenment myth that the best idea will prevail through struggle, so 'novelty' sometimes uncritically translates into 'good'), but also needs validation vis-à-vis established knowledge.

Compared to the task of teaching and serving at various levels of academic institutions (e.g. department, college and university), it is in the context of publishing that academic work reveals the most insidious sides of knowledge work: as a work that becomes boundless, as it becomes the kind of production that relocates in the interstitial space between work place and home, public and private sphere, and maintains academic workers always in 'on-line' status. 


\subsection{The Political Economy of Teaching}

While the production and publication of new knowledge represents a distinctive characteristic of them, most academicians work in institutions who employ them for the most part as teachers thus prevalently engaged in re-production rather than production of knowledge. Their task as instructors reflect once again a contradictory class location worth to be considered. On the one hand, academicians may consider themselves as inhabiting a managerial position of control and leadership. First of all, in the sense of directing the pedagogic projects/objectives linked to a university course, which manifest in the shaping of syllabi activities. Second, through a constant system of evaluation and disciplinization, teachers shape and 'subject' individuals, thus contributing to the societal apparatus that make people 'docile bodies' (Foucault 1977). Thirdly, the process of reproduction of knowledge through attending courses and credits gaining, and the various technique of evaluation is productive as cultural capital, thus placing academicians in key managerial positions in the political economy of certification which allow students to gain access to better paid occupations.

On the other hand, teaching in a neoliberal environment, especially pronounced in the US, reveals how the subjection process previously mentioned also concerns academicians as well. In fact, the commodification of higher education produces an interesting process that alienates teachers from the just mentioned power/control over knowledge production and 'emancipates' students by significantly reconfiguring the relations of production. Teachers tend to increasingly lose control over the pedagogy and academic freedom because they become retailers of educational commodities, thus turning syllabi into de facto contracts with quasi legal binding. Students become demanding customers who definitively enjoy the progressive side that capitalism, with eternal revolutionizing conveys. Thus, paradoxically enough, the neoliberalization of education carries a twisted and partial emancipation of students from the power-relations based on the principle of authority of the traditional teacherstudents rapport that Freire (1970) so strongly denounced.

\section{Conclusions: A Dialectical Narrative}

According to Nancy Fraser, progressive forces supportive of the mainstream trends of new social movements dedicated to the defence of identity politics - i.e. feminism, anti-racism, multiculturalism, and LGBTQ rights - have allied themselves with financial and cognitive capital. The outcome, as Fraser (2017) puts it, shows that "unwittingly, the former lends their charisma to the latter. Ideals like diversity and empowerment, which could in principle serve different ends, now gloss policies that have devastated manufacturing and what were once middle-class lives." Liberalindividualist understandings of "progress", so well represented in the highly contradictory California ideology (Barbrook and Cameron 1996) and the Clinton's saga, gradually replaced the more expansive, anti-hierarchical, egalitarian, class-sensitive, anticapitalist understandings of emancipation that had flourished in the 1960s and 1970s. In this sense, while concentrating on the US humanities for this analysis, and with rapprochements coming from both the radical right and radical left, humanities academicians are considered not only as hypocritical due to a preaching of social reform out a position of privilege, but also as an important representative of the so called "progressive neoliberalism" that Fraser (2017) contends therefore, aware and, most importantly, unaware artificers of neoliberal hegemony.

As we mentioned earlier, the dialectics of intellectual labour seems to be a distinctive feature of this profession, which has been also aggravated by recent drastic changes in the economic and social experience of the academic worker. The contra- 
dictory class positionality of academic knowledge workers has led to growing instability in finding permanent work while the knowledge labour produced continues to necessarily function as commodity exchange for financial capital and stability. At the same time, with a growing sentiment of rejection of this profession armed by antiintellectualist rhetoric, scholars continue to push through the pressures of academic departments operating in staunch neoliberal conditions. Hence, while academic labour experiences higher and higher level of capital subsumption - thus in many ways more integrated with dominant dynamics of cognitive/knowledge/informational capital accumulation, its liminal position still cannot find a comfortable place in the social organisation of production.

We claimed that those 'objective' conditions contribute to shape subjectivities that are impacted by import forces such as a continuous condition of debt; the constant struggle to maintain 'employability,' a considerable degree of intellectual property rights and intellectual freedom, a drastic re-configuration of the teacher-student relationship and loss of academic freedom. Thus, academic production, intellectual labour and work, the political economy of publishing and teaching, and the goal of obtaining 'employability' are all factors that continue to add to the precarious nature of workers in academia.

We tried to point out both 'objective' and 'subjective' levels of intellectual labour by centring our focus on material production in the academy. We tried to illuminate how the historical valorization of knowledge production and reproduction continues to push a post-Fordist intellectual capitalism that forces academic workers to capitalize on all available intellectual and cognitive abilities. Further, the influence of such an 'intellectualized' capitalism not only allows for the colonization of disposable leisure time, but becomes the driving force behind the need for self-exploitation in a political economy of publishing that continues to centralize itself around increased subjective alienation. The contradictory nature of academic validation and economic security in the continuously exploited academy are sites of contention that not only drive the precarious positionality of the intellectual worker, but also force the academic worker to experience increasingly unstable academic departments.

More specifically related to our field of study, while capitalism is consistently inhabited by profound contradictions that create crises and rupture points, we also tried to incorporate communication and media studies both as a discipline as well as labour into a dialectical understanding of the social whole. We think that such a communicative perspective is necessary in a moment in which a new spirit of capitalism (Boltanski and Chiappello 2007) so effectively subsumes its own contradictions as extending the process of value creation to the entirety of social life (Dyer-Witheford 1999). Such permeation flattens the world into a one-dimensional playground in which commodified culture tends to lose its function as a positive estrangement moment (Marcuse 1964).

Finally, by defining academicians as specialized representatives of knowledge work, thus as labourers, means to push back against two idealist notions. The first one conveyed by the figure of the "traditional intellectual" in a Gramscian sense $(1975,474)$ which assumes to be outside history, beyond ideological dispute, and, in doing so, reifies the existing hegemony. The second one conveyed by a distortion of Gramsci's "organic intellectual" $(1975,476)$, which materializes in the socially responsible progressive public intellectual, who intervenes in the world based on an abstract notion of social justice, equality and 'power,' and who, out of vocation, ideals, and ideology, needs to find a normative justification of his/her occupation outside of it. Such a conceptualization represents, in our view, the opposite of what an organ- 
ic intellectual should aspire to, and in the end turns out to be another version of the traditional intellectual. That is because such a notion assumes academicians to behave as intellectual archangels coming down to earth to save the world instead of being subjects completely embedded in the whole social process as workers.

While for Gramsci we are all involved in some intellectual activity, we cannot all function as organic intellectuals, and this is true for academic workers as well. The automatic identification of our intellectual labour, with the political function attributed by Gramsci to intellectuals, should not be considered as a given. Clearly, we are not saying that academicians should not get involved in political projects, but rather, that we believe that mobilization should have a degree of organicity with the class they belong to, and therefore, starting from the particular location in the material production of a given society. It is in fact in the material terrain of working that one becomes aware of the larger social contradictions based on class specific condition of exploitation and precarization of work (Archer 2008). In this sense, Autonomist Marxism literature (e.g. Hardt and Negri 2000; Berardi 2009) points out how specific the postFordist conditions of production, together with the specific subjectivities of workers valorizing knowledge, culture and relational skills, possesses an emancipatory potential to develop a critical consciousness that can challenge present capitalism.

In the academic world, this is exemplified by the kind of mobilization enacted by initiatives such as Precarious Workers Brigades and Carrot Workers Collective (2014) in the UK, Quinto Stato in Italy, or the Cultural Workers Organize in Canada and their effort to produce a number of practical tools to survive as knowledge workers, while denouncing how higher education is normalizing precarity.

\section{References}

Archer, Louise. 2008. The New Neoliberal Subjects? Young/er Academics' Constructions of Professional Identity. Journal of Education Policy 23 (3): 265-285.

Armano, Emiliana and Annalisa Murgia. 2017. Hybrid Areas of Work in Italy. Hypotheses to Interpret the Transformations of Precariousness and Subjectivity. In Mapping Precariousness, Labour Insecurity and Uncertain Livelihoods: Subjectivities and Resistance, edited by Emiliana Armano, Arianna Bove and Annalisa Murgia, 47-59. London: Routledge.

Barbrook, Richard and Andy Cameron. 1996. The Californian Ideology. Science as Culture 6 (1): 44-72.

Beck, Ulrich. 2000. What is Globalization? Hoboken: Wiley Publishing.

Berardi, Franco. 2009. Precarious Rhapsody, Semiocapitalism and the Pathologies of the Post-Alpha Generation. London: Minor Compositions.

Berlant, Lauren. 2011. Cruel Optimism. Durham: Duke University Press.

Bloom, Peter. 2013. Fight for Your Alienation: The Fantasy of Employability and the Ironic Struggle for Self-Exploitation. ephemera: theory \& politics in organization 13 (4): 785-807.

Boltanski, Luc and Eve Chiapello. 2007. The New Spirit of Capitalism. London: Verso.

Bourdieu, Pierre. 1988. Homo Academicus. Stanford: Stanford University Press.

Bourdieu, Pierre. 1977. Outline of a Theory of Practice. Cambridge: Cambridge University Press.

Bratich, Jack Z. 2008. From Embedded to Machinic Intellectuals: Communication Studies and General Intellect. Communication and Critical/Cultural Studies 5 (1): 24-45.

Briziarelli, Marco. 2013. (Re-)Occupy Critique! The Condition of Theory and Praxis in Contemporary American Academia. Graduate Journal of Social Science 10 (3): 54-79.

Brown, Laura, Rebecca Griffiths and Matthew Rascoff. 2007. University Publishing in a Digital Age. Journal of Electronic Publishing 10 (3). Accessed September 27, 2017. https://doi.org/10.3998/3336451.0010.301 
Castells, Manuel. 1996. The Rise of the Network Society: The Information Age: Economy, Society, and Culture. Hoboken: Wiley Publishing.

Clarke, Caroline, David Knights and Carol Jarvis. 2012. A Labour of Love? Academics in Business Schools. Scandinavian Journal of Management 28 (1): 5-15.

Court, Stephen and Gall Kinman. 2008. Tackling Stress in Higher Education. London: University and College Union. Accessed September 27, 2017. https://www.ucu.org.uk/media/3021/Tackling-stress-in-higher-education-UCU-surveyfindings-Dec-08/pdf/ucu hestress dec08.pdf

Davies, Bronwyn and Eva B. Petersen. 2005. Intellectual Workers (Un)Doing Neoliberal Discourse. Critical Psychology 13: 32-54.

Denning, Michael. 2004. Culture in the Age of Three Worlds. New York: Verso.

Discenna, Thomas. 2011. Academic Labor and the Literature of Discontent in Communication. International Journal of Communication 5: 1843-1852. Accessed September 27, 2017. http://ijoc.org/index.php/ijoc/article/view/1301/661

Dyer-Witheford, Nick. 1999. Cyber-Marx. Cycles and Circuits of Struggle in High Technology Capitalism. Urbana: University of Illinois Press.

Eagleton, Terry. 2000. The Idea of Culture. London: Wiley.

Etzkowitz, Henry, Andrew Webster and Peter Healey, ed. 1998. Capitalizing Knowledge: New Intersections of Industry and Academia. Albany: State University of New York Press.

Finn, Dann. 2000. From Full Employment to Employability: A New Deal for Britain's Unemployed? International Journal of Manpower 21 (5): 384-399.

Foucault, Michel. 1977. Discipline and Punish. The Birth of the Prison. Harmondsworth: Penguin Books.

Fraser, Nancy. 2017. Against Progressive Neoliberalism, A New Progressive Populism. Dissent, January 28. https://www.dissentmagazine.org/online articles/nancy-fraser-againstprogressive-neoliberalism-progressive-populism

Freire, Paulo. 1970. Pedagogy of the Oppressed. New York: Continuum.

Fuchs, Christian. 2016. Critical Theory of Communication: New Readings of Lukács, Adorno, Marcuse, Honneth and Habermas in the Age of the Internet. London: University of Westminster Press.

Fuchs, Christian. 2010. Labour in Informational Capitalism and on the Internet. The Information Society 26 (3): 179-196.

Fuchs, Christian. 2009. Information and Communication Technologies and Society: A Contribution to the Critique of the Political Economy of the Internet. European Journal of Communication 24 (1): 69-87.

Gallino, Luciano. 2001. The Human Cost of Flexibility. Rome: Editori Laterza.

Gill, Rosalind. 2014. Academics, Cultural Workers and Critical Labour Studies. Journal of Cultural Economy 7 (1): 12-30.

Gill, Rosalind. 2010. Breaking the Silence: The Hidden Injuries of the Neoliberal University. In Secrecy and Silence in the Research Process: Feminist Reflections, edited by Róisín Ryan-Flood and Rosalind Gill, 228-244. London: Routledge.

Giustiniano, Luca and Federica Brunetta. 2015. Rethinking Employability: New Managerial Competencies in a Global Labour Market. Sociologia del lavoro 137: 17-35.

Gorz, Andre. 2010. The Immaterial. Chicago: University of Chicago Press.

Gramsci, Antonio. 1975. Quaderni dal Carcere. Turin: Einaudi.

Hall, Stuart. 1992. The Question of Cultural Identity. In Modernity and its Futures, edited by Stuart Hall, David Held and Anthony McGrew, 274-316. Cambridge: Polity Press.

Hardt, Michael and Antonio Negri. 2004. Multitude. New York: Penguin.

Hardt, Michael and Antonio Negri. 2000. Empire. Cambridge: Harvard University Press.

Hesmondhalgh, David and Sarah Baker. 2011. Creative Labour: Media Work in Three Cultural Industries. London: Routledge.

Hillage, Jim and Emma Pollard. 1998. Employability: Developing a Framework for Policy Analysis. Suffolk: Department for Education and Employment. 
Horkheimer, Max and Theodor Adorno. 1974. The Dialectics of Enlightenment. London: Verso.

Huws, Ursula. 2014. Labor in the Global Digital Economy: The Cybertariat Comes of Age. New York: Monthly Review Press.

Koloğlugil, Serhat. 2015. Digitizing Karl Marx: The New Political Economy of General Intellect and Immaterial Labor. Rethinking Marxism 27 (1): 123-137.

Lazzarato, Maurizio. 2015. Governing by Debt. Los Angeles: Semiotext(e).

Lazzarato, Maurizio. 1996. Immaterial Labor. In Radical Thought in Italy: A Potential Politics, edited by Paolo Virno and Michael Hardt, 133-146. Minneapolis: University of Minnesota Press.

Lorenz, Chris. 2012. If You're So Smart, Why Are You Under Surveillance? Universities, Neoliberalism, and New Public Management. Critical Inquiry 38 (3): 599-629.

Marcuse, Herbert. 1964. One Dimensional Man: Studies in the Ideology of Advanced Societies. New York: Beacon Press.

Marx, Karl. 1990. Capital: A Critique of Political Economy, Volume 1. New York: Penguin.

Marx, Karl. 1973. Grundrisse. London: Penguin.

Marx, Karl. 1907. The Eighteenth Brumaire of Lois Bonaparte. New York: Charles H. Kerr \& Co.

McRobbie, Angela. 2015. Be Creative: Making a Living in the New Culture Industries. London: Polity.

Peekhaus, Wilhelm. 2012. The Enclosure and Alienation of Academic Publishing: Lessons for the Professoriate. tripleC: Communication, Capitalism \& Critique 10 (2): 577-599. Accessed September 27, 2017. http://www.triple-c.at/index.php/tripleC/article/view/395

Pico della Mirandola, Giovanni. 1942. De hominis dignitate, Heptaplus, De ente et uno e scritti vari. Florence: Vallechi.

Precarious Workers Brigade and Carrot Workers Collective. 2014. Free Labour Syndrome. Volunteer Work and Unpaid Overtime in the Creative and Cultural Sector. In Joy Forever: The Political Economy of Social Creativity, edited by Michał Kozłowski, Angieszka Kurant, Jan Sowa, Krystian Szadkowski and Jakub Szreder, 211-226. London: MayFlyBooks.

Radder, Hans. 2010. The Commodification of Academic Research: Science and the Modern University. Pittsburgh: University of Pittsburgh Press.

Readings, Bill. 1996. The University in Ruins. Cambridge: Harvard University Press.

Said, Edward. 1993. Culture and Imperialism. London: Chatto and Windus.

Salecl, Renata. 2010. The Tiranny Choice. London: Profile Books.

Striphas, Ted. 2010. Acknowledged Goods: Cultural Studies and the Politics of Academic Journal Publishing. Communication and Critical/Cultural Studies 7 (1): 3-25.

Terranova, Tiziana. 2000. Free Labour: Producing Culture for the Digital Economy. Social Text 18 (2): 33-57.

Virno, Paolo. 1996. Notes on the "General Intellect". In Marxism beyond Marxism, edited by Saree Makdisi, Cesare Casarino and Rebecca Karl, 265-272. London: Routledge.

Wright, Erik Olin. 1997. Class Counts. Comparative Studies in Class Analysis. Cambridge: Cambridge University Press.

Wright Mills, Charles. 1951. White Collar: The American Middle Classes. Oxford: Oxford University Press.

\section{About the Authors}

\section{Marco Briziarelli}

Marco Briziarelli studies critical approaches to media and communication theory, especially as these fields intersect with broader issues in political and social theory, intellectual and cultural history. The work he has published in the last years has consistently tried to articulate the link between two united but distinct research interests, namely political economy of (digital) media and media and social movements. 
Joseph L. Flores

Joseph L. Flores received his BA (2011) and MA (2015) degrees from the University of Texas at El Paso. With a broad interest in political, cultural and social theory, Joseph takes a critical approach to understanding how communication impacts social media use, social movements and digital labour. Specifically, he is interested in political and social discourse through mediated forms of communication that carry social, political and cultural consequences. 